\begin{tabular}{|c|c|c|}
\hline \hline & International Journal of Current Research in \\
\hline & Biosciences and Plant Biology \\
\hline EXCELLENT \\
PUBLISHERS
\end{tabular}

\title{
New distributional record of Zeuxine strateumatica (L.) Schltr. (Orchidaceae) to the State Flora of Gujarat from Sabarkantha district, India
}

\author{
S. K. Patel ${ }^{*}$, K. C. Patel ${ }^{2}$, B. L. Punjani², T. R. Nayi ${ }^{2}$ and P. R. Desai ${ }^{2}$ \\ ${ }^{1}$ Department of Biology, Gujarat Arts and Science College, Ellis bridge, Ahmedabad, Gujarat, India \\ ${ }^{2}$ Department of Botany, Smt. S. M. Panchal Science College, Talod, Sabarkantha District, Gujarat, India \\ *Corresponding author; e-mail: sk_8003@yahoo.com
}

\begin{tabular}{ll}
\hline Article Info & ABSTRACT \\
\hline $\begin{array}{l}\text { Date of Acceptance: } \\
\text { 20 April 2020 }\end{array}$ & $\begin{array}{l}\text { The present study found new distributional record of Zeuxine strateumatica } \\
\text { (L.) Schltr., a terrestrial orchid belonging to family Orchidaceae to the Gujarat } \\
\text { state flora from Sabarkantha district of North Gujarat Region. In addition to } \\
\text { this the relevant citation, description, flowering and fruiting period, field notes } \\
\text { o6 May } 2020\end{array}$ \\
$\begin{array}{ll}\text { Keywords } \\
\text { and photographs are provided here for easy identification. }\end{array}$ \\
$\begin{array}{l}\text { Sabarkantha District } \\
\begin{array}{l}\text { Talod } \\
\text { Terrestrial orchid } \\
\text { Zeuxine strateumatica }\end{array}\end{array}$ \\
\hline
\end{tabular}

\section{Introduction}

The district Sabarkantha is situated in the NorthEastern part of Gujarat State between 23.05000000-24.50000000 N and 72.7166666773.65000000 E. During our intensive botanical explorations in different areas in Sabarkantha district, an interesting plant species from Lebhor pond, Talod was collected, growing among grasses and sedges. Specimens were collected and properly processed for herbarium by using the standard herbarium methods (Jain and Rao, 1977). After critical examination with dissected floral parts and other morphological features and perusal of relevant literature available, the specimens were identified as Zeuxine strateumatica (L.) Schltr.
(Shah, 1978; Abraham and Vatsala, 1981). Zeuxine Lindl. is a very widespread genus distributed from Tropical Africa to Central Asia and West Pacific represented by 170 species distributed around the world (Govaerts et al., 2011) of which 18 species are found in India (Misra, 2007). Prior to this survey, however, the Orchidaceous genus Zeuxine Lindl. was represented by a single species, i.e., Zeuxine strateumatica (L.) Schltr. in Gujarat state as reported by different localities (Thaker, 1910; Shah,1978; Raghavan et al., 1981; Bole and Pathak,1988; Pilo et al., 1996; Bhatt, 2018). Sabarkantha district is recorded to be with rich in floristic diversity and it is well explored by various plant taxonomists (Saxton and Sedgwick, 1918; Saxton, 1922; Bhatt and Bedi, 1969; Yogi, 1970; 
Bhatt and Sabnis, 1987; Punjani, 1997; Patel, 2003; Pandey, 2011; Parmar, 2012). The species has not been reported from North Gujarat Region. So, it is a new distributional record from Sabarkantha district for Gujarat State. The distribution and current localities recorded of Zeuxine strateumatica (L.) Schltr. in Gujarat state is depicted in Fig. 1. A voucher specimen (SKP-081 and SKP-089) has been deposited at the Gujarat Arts and Science College, Ellisbridge, Ahmedabad, Gujarat. In addition to this the relevant citation, a brief description, phenological data, field notes and photographs are provided for easy identification of the species in the wild.

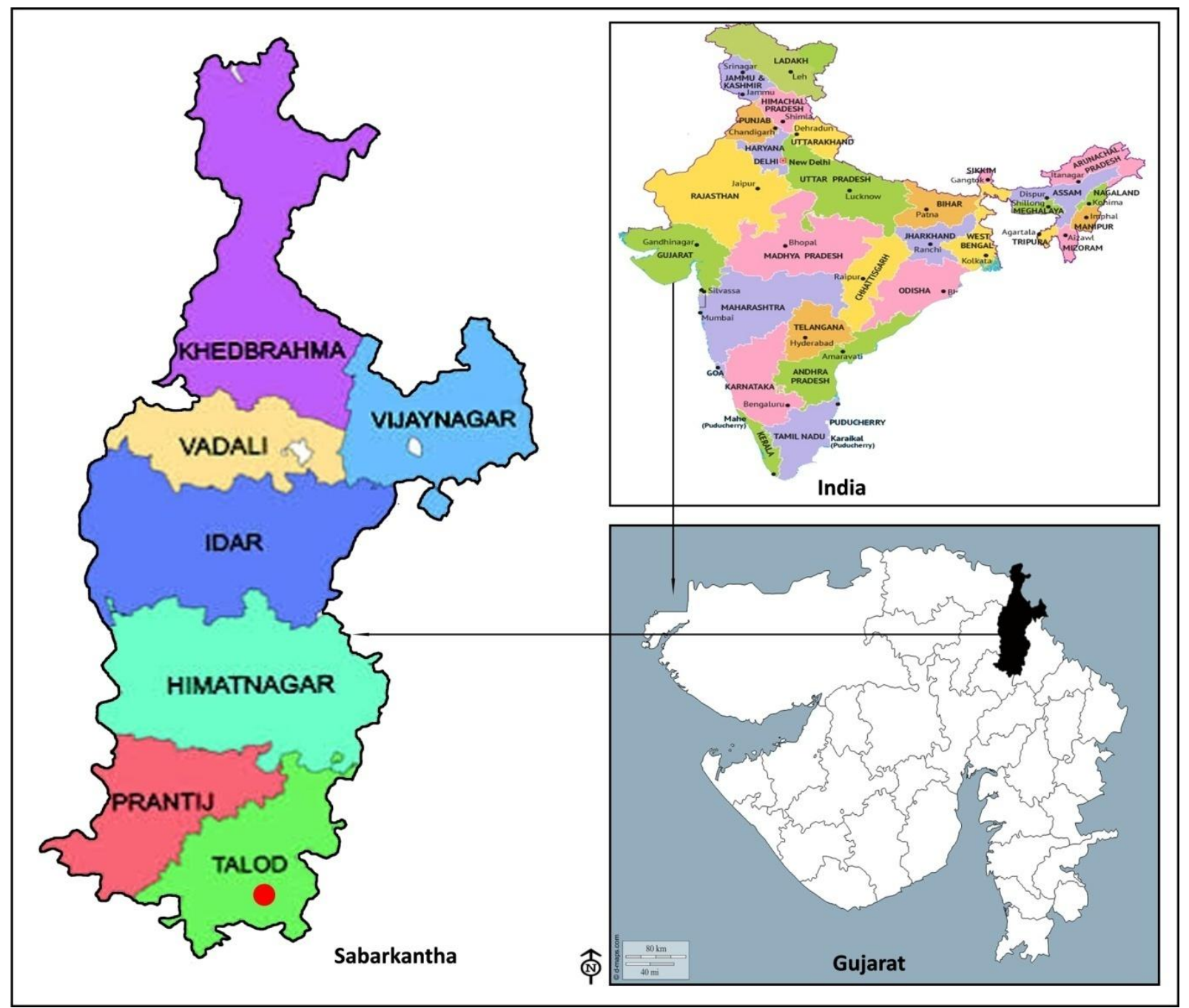

Fig. 1: Location map of Zeuxine strateumatica (L.) Schltr. In Talod, Sabarkantha District, Gujarat, India.

\section{Taxonomic description}

Zeuxine strateumatica(L.) Schltr. in Bot. Jahrb. Syst. 45: 394. 1911; Santapau and Kapadia, Orchids Bombay 167. t. 38. 1966; Shah, Fl. Gujarat 2: 663. 1978; Raghavan et al. in Bull. Bot. Surv. India 84, 1981; Pandey in Shetty and Singh, Fl. Rajasthan 2: 825. 1991; T. Cooke, Fl. Pres. Bombay 3: 213. 1958. (Fig. 2 a, b)
Terrestrial, erect, grass-like herbs, it is $8-30 \mathrm{~cm}$ high, growing from upper node of an ascending stem like rhizome. The Leaves are grass like, 2-8, clasping, erect, alternate, sessile, linear-lanceolate, acuminate and passing upward into foliar sheaths. Inflorescence terminal, erect, spike with 3-19 flowered, dense. Flowers sessile, not opening well, perianth oblique on ovary, white. Sepals unequal, obtuse; dorsal ovate, base saccate; laterals 
obliquely oblong-ovate, cymbiform. Petals falcately oblong lanceolate, subacute, cohering with dorsal sepal to form a hood over the column. Lip tongue shaped, with upturned sides, yellow; basal part saccate, bearing inside two obliquely oblong, blunt pillar glands; middle part contracted to a short claw; terminal lobe short, hunch backed, ovate in outline, mucronate, hammer headed, two-lobed, the lobes upturned, sub-quadrate; epichile 2-lobed, sometimes appearing 1-lobed, sub-reniform, yellow or greenish-yellow or brownish-white, margin entire.

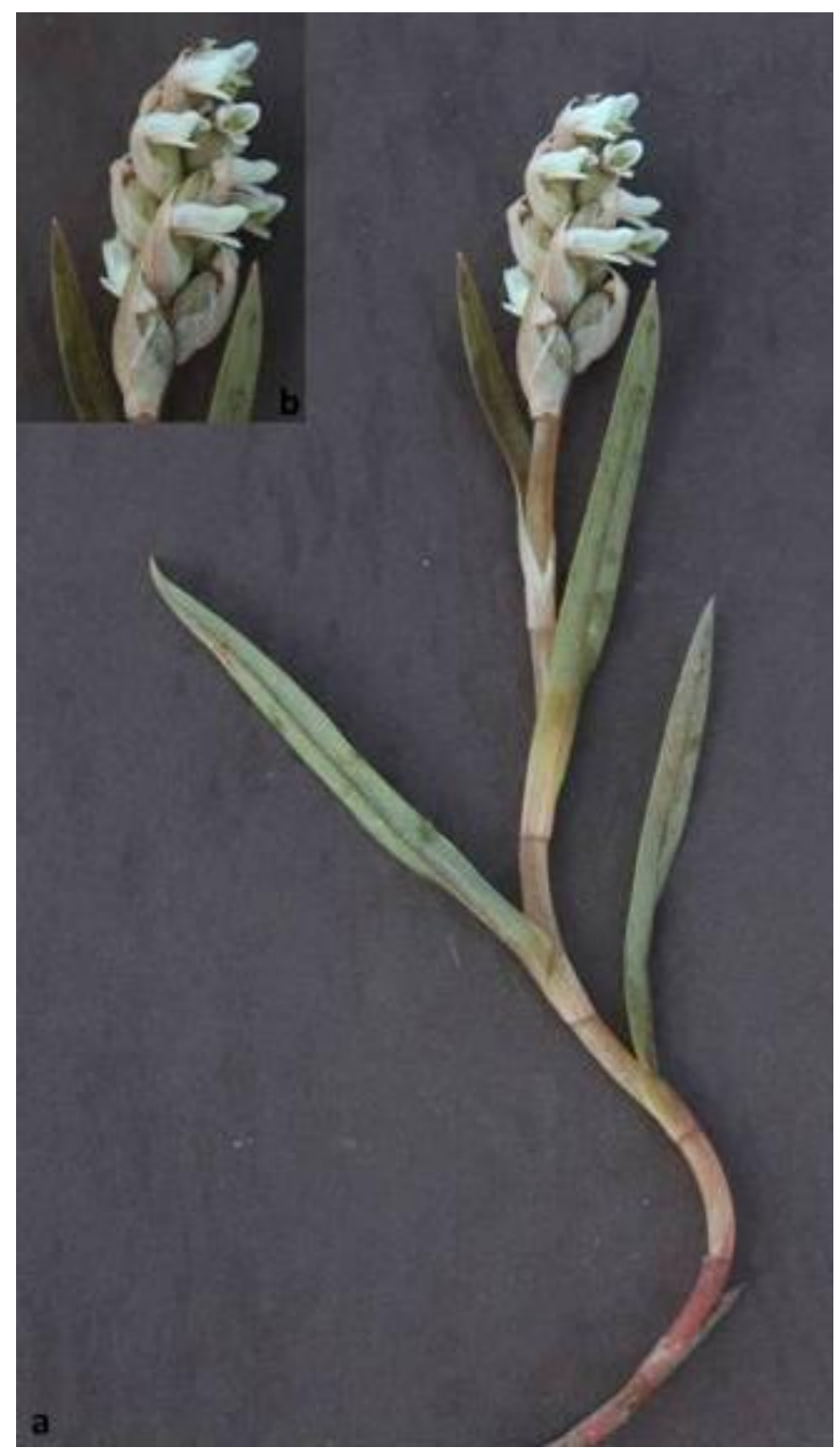

Fig. 2: Zeuxine strateumatica (L.) Schltr; a. Whole plant b. close up view of flowers.
Flowering and fruiting: February - March

Specimen examined: Lebhor Pond, Talod, Sabarkantha District, Gujarat (GPS coordinate: $23.334785 \mathrm{~N} \& 72.952330$ E), SKP-081, Dt. 23.III.2019; SKP-o89, Dt. 20.II.2020

Field notes: The field investigation revealed that this species is found on the margin of the pond, closely associated with grasses and sedges(Several species of Cyperus, Eleocharis, Fimbristylis and Scirpus genera were frequently encountered and they exhibited very wide range of distribution in the area) and herb species like Ammania sp., Ludwigia sp., Polygonum sp., Bacopa monnieri (L.) Pennell, Limnophila heterophylla (Roxb.) Benth., they are surrounding associated species, while Ipomoea fistulosa Mart. ex Choisy, Typha angustifolia L. growing on the margin of the pond. The population of this orchid is confined to only one locality with eighty (80) individuals from Lebhor pond in Talod taluka of Sabarkantha district. This pond was previously a natural pond but the government dug up it and made it a bigger water reservoir for the surrounding farmers for the irrigation to their fields. Many threats in this area were found to be solid waste dumping, water pollution, manmade construction, habitat fragmentation, grazing and other anthropogenic pressure, these all factors could deplete the number of the species in its natural habitat in the future. If we want to conserve this species, a ban to these all harmful activities are urgently needed, otherwise species will be disappearing from the natural habitat.

Many importance species found in this pond like, Blyxa octandra (Roxb.) Planchon ex Thwaites, Dopatrium junceum (Roxb.) Buch.- Garten., Limnophyton obtusifolium (L.) Miq., Potamogeton perfoliatus L., Sagittaria sagittifolia L., Utricularia reticulata Sm., and Some pteridophytes viz. Azolla pinnata R. Br., Isoetes coromandeliana L. f., Marsilea minuta L. were also reported in the same wetland. In future, we have to give main priority to sustainable development, so that mankind gets enriched by combination of modern technology and beauty of the nature. Studies on wetland plants pertaining to their distribution pattern, status, major threats and other ecological aspects are also highly recommended. 


\section{Conflict of interest statement}

Authors declare that they have no conflict of interest.

\section{Acknowledgement}

The authors are thankful to Dr. B. L. Punjani, Principal, Smt. S. M. Panchal Science College, Talod Sabarkantha district for his constant support during the field work and encouragement. We would also like to extend our sincere gratitude to our colleagues for their support.

\section{References}

Abraham, A., Vatsala, P., 1981. An introduction to Orchids with Illustrations and Description of 150 South Indian Orchids. Tropical Botanical Garden and Research Institute, Trivandrum.

Bhatt, M. R., 2018. Systematic studies on Orchidaceae of Gujarat. Ph.D. Thesis, The Maharaja Sayajirao University of Baroda, Gujarat.

Bhatt, R. P., Sabnis, S. D., 1987. Contribution to the Ethnobotany of Khedbrahma region of North Gujarat. J. Econ. Tax. Bot. 9, 139-145.

Bhatt, R. P., Bedi, S. J. 1969. A study of the vegetation and flora of Khedbrahma region of North Gujarat. Botanical Survey of India. JJ(3 J), 1-321.

Bole, P.V., Pathak, J.M., 1988. Flora of Saurashtra, Part-II \& III. Botanical Survey of India, Calcutta.

Cooke, T.H.,1958. The Flora of the Presidency of Bombay, Vol. I-III, Botanical Survey of India, Calcutta. (Reprinted).

Govaerts, R., Pfahl, J., Campacci, M. A., Baptista, D. H., Tigges, H., Shaw, J., Cribb, P., George, A., Kreuz, K., Wood, J., 2011. 134 World Checklist of Orchidaceae. The Board of Trustees 135 of the Royal Botanic Gardens, Kew. Retrieved on 2 March, 2012.

Jain, S. K., Rao, R. R., 1977. Field and Herbarium Methods. Today and Tomorrow's Printers and Publishers. New Delhi, India.
Misra, S., 2007. Orchids of India - A Glimpse. Bishen Singh Mahendra Pal Singh, Dehradun. p. $v+402$.

Pandey, V.B., 2011. Plant Species Diversity and their Ethnobotanical study in Tribal area of Bhiloda (West) Forest range of Sabarkantha district (North Gujarat). Ph.D. Thesis, Hem. North Gujarat University, Patan, Gujarat.

Parmar, P.J., 2012. A checklist of the Vascular Plants of Sabarkantha District, Gujarat, India. Nelumbo. 54, 92-137.

Patel, S.K., 2003. A contribution to the Flora of Meghraj and Malpur talukas of Sabarkantha District of North Gujarat. Ph.D. Thesis, Hem. North Gujarat University, Patan, Gujarat.

Pilo, B., Pathak, B.J., Kumar, B.A., Muruksan, V.K., Vinod, K.R., Kumari, S., 1996. Biological Diversity of Gujarat - Current knowledge. Gujarat Ecological Commission (GEC), Vadodara.

Punjani, B.L., 1997. An Ethnobotanical Study of Tribal Areas of District Sabarkantha (Gujarat). Ph.D. Thesis, Hem. North Gujarat University, Patan, Gujarat.

Raghavan, R. S., Wadhwa, B. M., Ansari, M. Y., Rao, R. S., 1981. A check list of plants of Gujarat. Records of Botanical Survey of India. 21(2), 1 -127.

Santapau, H., Kapadia, Z. 1966. The Orchids of Bombay. Govt. of India Press, Calcutta, vi+239pp

Saxton, W.T., 1922. Additional notes on plants of Northern Gujarat. Records of Botanical Survey of India. 9, 251-262.

Saxton, W.T., Sedgwick, L.J., 1918. Plants of Northern Gujarat. Botanical Survey of India. 6(7), 209-323 and i-xiii.

Shah, G.L., 1978. Flora of Gujarat State, Part I and II. Sardar Patel University Press, Vallabh Vidyanagar,Gujarat.

Thaker, J.I., 1910. Vanaspati shastra, (Flora of Bardahill). Reprint, Pravin Pustak, Bhandar, Rajkot.

Yogi, D.V., 1970. A contribution to the flora of North Gujarat. Ph. D. Thesis, Sardar Patel University, Vallabh Vidhyanagar, Gujarat.

\section{How to cite this article:}

Patel, S. K., Patel, K. C., Punjani, B. L., Nayi, T. R., Desai, P. R., 2020. New distributional record of Zeuxine strateumatica (L.) Schltr. (Orchidaceae) to the State Flora of Gujarat from Sabarkantha district, India. Int. J. Curr. Res. Biosci. Plant Biol. 7(5), 36-39. doi: https://doi.org/10.20546/ijcrbp.2020.705.005 